\title{
Sir William Paton (1917-93)
}

Sir William (Drummond Macdonald) Paton, who died on 17 October 1993, was a worldclass pharmacologist. Born on 5 May 1917 into a strongly ecclesiastical family - his father was a DD, two brothers were distinguished Anglican priests also, and his sister married the present Bishop of Birmingham - he departed from this pattern at Repton and took a First in Physiology at Oxford in 1938. Reading medicine with considerable distinction at University College Hospital Medical School he received the appropriate Oxford degrees in 1944, two years after his marriage. Some of his finest pharmacological research was done during eight years at the National Institute for Medical Research (1944-52) after which he returned briefly to UCL as Reader before assuming his first professorship at the Royal College of Surgeons in 1954. Two years later he was elected FRS, serving on the Council of the Royal Society from 1967 to 1969. Paton's election to the Chair of Pharmacology at Oxford occurred in 1959, when he also became a Fellow of Balliol. He was awarded the CBE in 1968 and was knighted in 1979.

This is no place for an account of Paton's scientific discoveries or of the useful results that flowed from them, nor for treating his influence on national affairs through service on innumerable committees. To historians of science Bill Paton is known as a successful and creative editor of the Notes and Records of the Royal Society from vol. 26 (1971) to vol. 43 (1989). In the same period he undertook the chairmanship of the British National Committee for the History of Science, Medicine and Technology, exercising a solid influence on the national support for research in these fields.

Notes and Records had enjoyed a long and stimulative editorship under Sir Harold Hartley, with whom Professor R. V. Jones had jointly edited vols. 24 and 25; Professor Jones continued as joint editor for the next eighteen years with Paton. (Norman Robinson, whose father - like himself, Librarian to the Royal Society - had founded the journal, was throughout managing editor.) A note on 'Editorial Policy' by the new team at the opening of their first joint volume pointed out that Notes and Records not only welcomed scholarly papers on the history of the Royal Society and of its individual Fellows, but would find room for work of wider scope, quoting J. C. Maxwell on the need for the history of science 'to tell of unsuccessful enquiries' and explain why some of the 'ablest men have failed to find the key of knowledge'. Further, the activities of Fellows outside science might be of interest: excellent examples of the 'human interest' of scientists in Notes and Records are Sherrington's reminiscences of a Birmingham shell factory in 1915 (vol. 39) and Kapitza's amusing letters to his mother about the Cavendish Laboratory (vol. 43). More serious contributions came from both professional historians of science and Fellows of the Royal Society (including both Jones and Paton), while the total bulk of the journal increased so that the eighteen volumes $26-43$ occupy more shelf-space than the preceding twenty-five. Paton had no tolerance for folly nor patience with any work less than the best of its kind. Neither editor felt the need to shelter behind referees' doubts and questions: if a paper failed to interest and satisfy them it was out. 
Equally, Bill Paton was for some years a well-known figure in history of medicine as Honorary Director of the Wellcome Institute (1983-87). He had been chosen a Wellcome Trustee in 1978 - a post in which he was very active - and stepped in to take charge of the Institute at the beginning of a period of considerable change and development. His dual capacity enabled him to enhance the scholarly potential of the Institute and encourage its educational role. Having a real love of history and of books - in a small way he was a collector himself - his position at the Institute was highly congenial to him.

Sir William Paton had long suffered from a chronic respiratory condition - which failed to banish altogether his favourite small cigars - and though he remained en poste to the usual retiring age he adopted in retirement a rather reclusive way of life. He was happy to live with his wife, his books and his garden.

A. Rupert Hall 